\title{
ASSESSING THE EFFECTS OF MECHANIC ACTIVITIES ON UYO AIR ENVIRONMENT *Ekong, F.U., ${ }^{1}$ Michael, G.U.S. ${ }^{1}$ and Michael, U.S. ${ }^{2}$ DOI: http://dx.doi.org/10.4314/ejesm.v5i1.9
}

\author{
Received $13^{\text {th }}$ September 2010; accepted $12^{\text {th }}$ February 2012
}

\begin{abstract}
Prior to the advancement of science and technology, our air was fresh, and wholesome. Expansion in the economic sector one of which is mechanic workshops brought along with it advantages and disadvantages, one of which is air pollution. Activities carried out in these workshops included engine repairs, paneling, open spray painting, vulcanizing, hammering, riving of engines, fabrication of worn-out metal parts, among others. The air environment of these workshops began to be loaded with obnoxious gases such as sulphur dioxide, nitrogen oxide, ozone, hydrocarbons, among others. This study therefore seeks to assess the effect of mechanic activities on Uyo air environment. Twenty-one sample locations were selected for air quality analysis and compared with the control location. Multiple regression analysis showed a strong significant relationship between auto mechanic activities and the present level of pollution in Uyo air environment. The study recommended that all the obnoxious gases should be reduced at source through proper land use zoning to ensure a sustainable air environment in the face of growing climate change.
\end{abstract}

Keywords: Auto mechanics, Air pollution, Environment, Land use planning, Mechanic village

\section{Introduction}

Automobiles constitute one of the major modes of transportation for conveying people and goods in any nation of the world. The usefulness of this mode of transportation is not without cost. The major cost is pollution of different magnitude. Halls (1972) classified the pollution cost of automobile transportation into two main groups such as operational and the maintenance cost. The operational cost of automobile transportation occurs when vehicles are driven from one place to the other while the maintenance dimension occurs during vehicle repairs. Robinson \& Robinson (1970) observed that $48 \%$ of total atmospheric pollution comes from these two forms of automobile activities. Their major gaseous pollutants are sulphur dioxide, nitrogen oxide, ozone, carbon monoxide and hydrocarbons.

International fora such as Earth Summit focused more attention on the reduction of operational cost of automobile pollution by recommending the use of ethanol and hydrogen as alternative fuel for powering automobiles, removal of lead from gasoline, use of electric trains for inner city transportation, etc. Most of these suggestions have been implemented in some developed countries while some have been interpreted into local contents of some developing

${ }^{1}$ Department of Urban and Regional Planning, University of Uyo,

P.M.B. 1017, Uyo, Akwa Ibom State, Nigeria.

${ }^{2}$ Department of Electrical Electronics Engineering, Akwa Ibom State

Polytechnic Ikot Osurua.

Corresponding author email: faith_ekong@yahoo.com countries waiting for implementation (Earth summit, 2002).

However, less attention is paid to pollution caused by the maintenance dimension of automobile transportation (auto mechanic activities). Auto mechanic activities are actually producing comparable amount of pollutants due to their intensive operations (Sax, 2001). Chemicals such as refrigerator gases used in vehicle air conditioners are made up of chlorofluorocarbons which when allowed to escape in larger quantities into the atmosphere can deplete the ozone layer and cause a green house effect (Bassuer, 1987). This situation can not be allowed to continue especially with the current changes in climate within the region as shown by Atser et al, (2010) study.

The use of chemical solvents and fumes may cause lower ground ozone/smog formation and global warming (Wikipedia, 2009). Acid rain arising from the chemical reactions between atmospheric gasses and rain water can corrode zinc, paintings, monuments, buildings, etc thus destroying the aesthetic quality of the environment, leading to accelerated slum formation (Weiss, 1980). 


\section{Statement of Problems}

The menaces of automobile mechanic activities have been a serious concern to governments, stakeholders and non-governmental organizations all over the world. Presently though efforts are made in most developed countries to create a sustainable environment by imposing strict environmental regulations for auto mechanic workshops. Provision of environmental review that covers servicing, mechanical repairs in premises, sound environmental management system of waste generated and in extreme cases citing of these workshops are lacking in Nigeria. In Uyo urban activities carried out by auto mechanic operators does not comply with any of the standards set by international organizations or the Federal Ministry of Environment standards. There is indiscriminate citing of mechanic workshops and disposal of hazardous wastes such as brake fluid, greases, spent oil, radiator coolant, soot, fuel, metal scraps, chemicals and other volatile compounds into the air and the surrounding environment. These chemicals are not biodegradable and therefore persist in the environment.

Environmental pollutions following the activities of auto mechanics in Nigeria are not well documented except few works like Wong and Lau (1985); Iwegbue (2007) and Ipeaiyeda and Dawodu (2008). Wong and Lau (1985) for example noted that this sector of the economy is capable of producing pollutants that can determine the microclimate condition and invariably the micro-organisms of the environment surrounding where they operate. While, Iwegbue, (2007) studied metal fractionation in soil profiles at automobile mechanic waste dumps around Port Harcourt, and observed that metals present were relatively mobile, but more in the surface than in the substrate. Implying that they could easily be carried away by rain water or any moving agent into the surrounding environment such as gardens where they are picked up by vegetables. On the other hand Ipeaiyeda and Dawodu, (2007) investigating the heavy metals contamination at the vicinities of reclaimed auto-mechanic workshops in Iwo, Nigeria observed that lead was the dominant contaminant up to $133 \pm 66 \mathrm{mg} / \mathrm{kg}$ and was quite mobile. Since these gases can persist in the environment there is an urgent need to assess the effect of this sector of the economy and like

Iwebgue, propose land use plan to curb the spread of pollutants from this important sector of the economy.

The aim of this study, therefore, is to assess the effect of auto mechanic activities on the Uyo air environment. To achieve this aim the following objectives were set out to:

- examine the different types of activities carried out in the randomly selected workshops;

- examine the air pollutants emanating from the workshops;

- assess the causes of air pollutants;

- observe the relationship existing between mechanic activities and Uyo air environment;

- recommend ways of reducing observed effects.

In doing this, the study will attempt to test the following hypothesis:

$\mathrm{H}_{\mathrm{o}}$ there is no significant relationship between mechanic activities and Uyo air environment.

$\mathrm{H}_{1} \quad$ there is significant relationship between mechanic activities and Uyo air environment

\section{Materials and Methods \\ Study Area}

Uyo urban constitute the study area (Fig.1). Uyo is a coastal city located less than $60 \mathrm{kms}$ from the Atlantic coastline. Initially, it was a small village with dispersed settlement pattern. It was thinly populated by peasant farmers with a land mass of not more than 16 square kilometers; farming was therefore the major land use of the area (Akwa Ibom state 1989). Now Uyo assumed prominence due to its dual capacity as a local government headquarters and as a state capital since 1987 thus necessitating the immigration of people from its surrounding villages and suburbs since the city is situated at the center of the state and is easily accessible. The result of this is increase in population, rapid urbanization and increase in number of vehicles on the generally narrow and little improved streets within the city. 


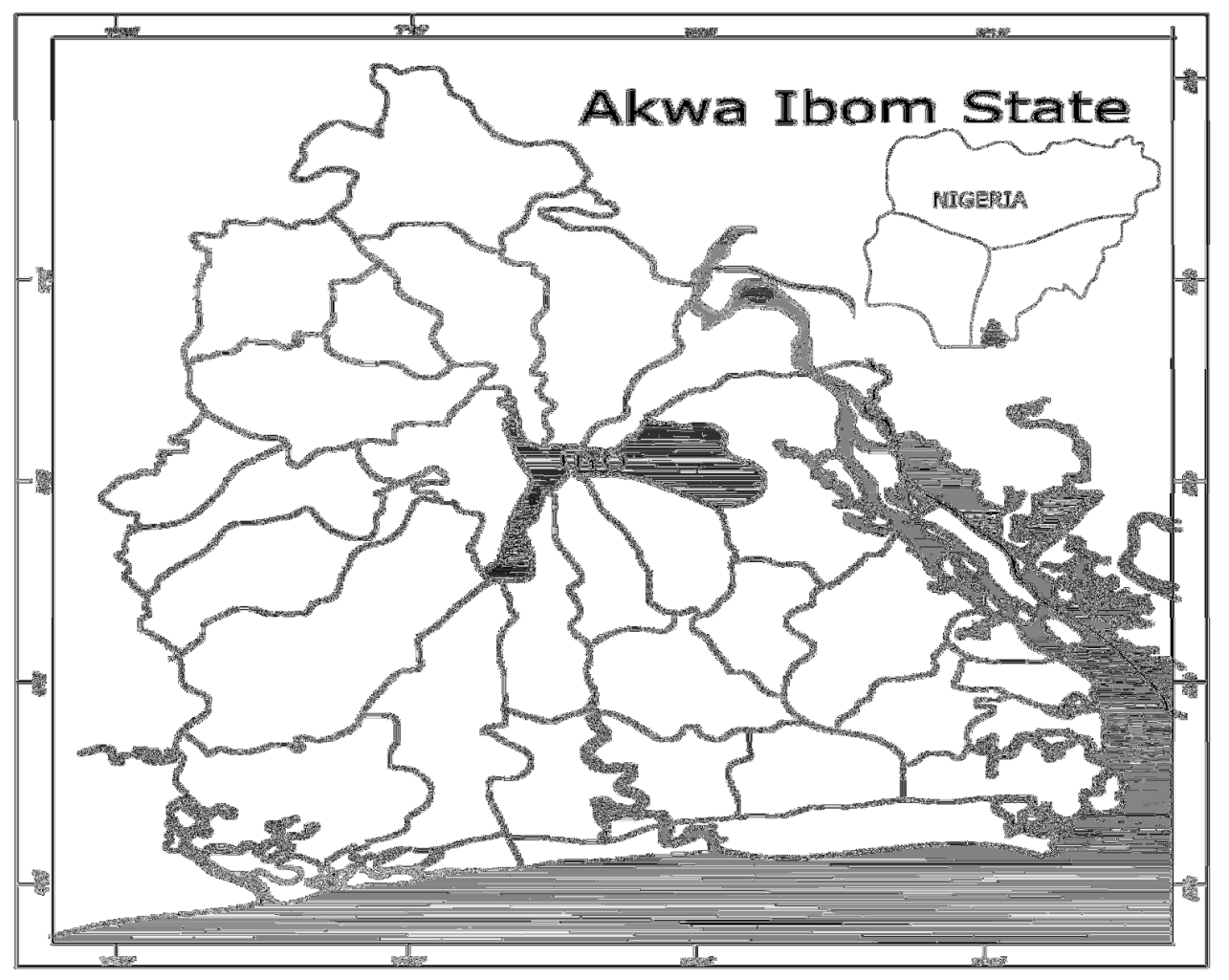

Figure1 Map of Akwa Ibom showing Uyo the study area

\section{Sample Collection}

In situ measurement of air sample was carried out in the randomly selected mechanic workshops using hand held air meters of models EQSA-0193092 for $\mathrm{SO}_{\mathrm{x}}$ analysis, $\mathrm{NO}_{\mathrm{x}}$ analyzer RFNA- 1292090 and model RFCA-0992-088 was used to analyze $\mathrm{CO}$ and $\mathrm{CO}_{2}$. Air sample for each location was taken at every 1 hour for 6 hours. Few hours were relevant because exposure at short duration can adversely affect humans. Samples were picked at points where there was uniform flow of gases i.e. during burning, welding points, during engine riving, air conditioning filling points, etc. It was picked at 8 stack diameter away from flow disturbances.

Each randomly selected workshop was given identity codes from 1-24 of the street name in Uyo Urban. The various gases measured situ was given codes such as $\mathrm{Co}_{2}$ (U10), Nox (U11), Co (U13), and so on. Codes and factors embedded in the independent variables (mechanic activities) include:
Area of the workshop

Number of vehicles repaired a day

Quantity of water used per day

Quantity of carbide used per day

Quantity of fuel used per day

Quantity of kerosene used per day

Quantity of paints used per day

This information was used to plot bar charts in order to observe the differences between the polluted and control environment. The multiple regression analysis was used to highlight the relationship existing between the dependent and the independent variables the effects of the dependent variable in explaining the variation in the independent variable and to test the null hypothesis $\left(\mathrm{H}_{\mathrm{o}}\right)$.

\section{Results and Discussions}

The summary of the gasses found in the randomly sampled auto mechanic workshops are presented in Table 1. It shows that twenty one workshops were sampled and used for this study. All the analysis for this study is based on them. 
Table 1 Summary of levels of gases found in the randomly selected Mechanic workshops

\begin{tabular}{lllll}
\hline Workshop codes & $\mathrm{Co}_{2}(\mathbf{U 1 0})$ & $\mathrm{No}_{\mathrm{x}}(\mathbf{U 1 1})$ & $\mathrm{So}_{\mathrm{x}}(\mathbf{U 1 2})$ & $\mathrm{Co}(\mathrm{U13})$ \\
\hline Eno19 & 0.4 & 0.2 & 0.4 & 0.4 \\
Ek11 & 0.2 & 0.2 & 0.2 & 0.2 \\
HR7 & 0.4 & 0.3 & 0.4 & 0.4 \\
Ikb14 & 0.4 & 0.4 & 0.3 & 0.2 \\
Ik12 & 0.2 & 0.1 & 0.01 & 0.01 \\
Js5 & 0.4 & 0.2 & 0.4 & 0.3 \\
Mw18 & 0.4 & 0.5 & 0.5 & 0.7 \\
NST 20 & 0.1 & 0.2 & 0.2 & 0.2 \\
NE2 & 0.6 & 0.4 & 0.6 & 0.4 \\
NE4 & 0.3 & 0.4 & 0.4 & 0.3 \\
Ok16 & 0.6 & 0.4 & 0.5 & 0.5 \\
Rd1 & 0.5 & 0.5 & 0.5 & 0.4 \\
Rd24 & 0.3 & 0.2 & 0.3 & $0.2 \mathrm{~s}$ \\
Udb17 & 0.3 & 0.4 & 0.3 & 0.3 \\
Uo9 & 0.02 & 0.3 & 0.4 & 0.3 \\
Us8 & 0.2 & 0.3 & 0.2 & 0.2 \\
Uu6 & 0.2 & 0.3 & 0.2 & 0.2 \\
Uk13 & 0.4 & 0.2 & 0.1 & 0.3 \\
Ut10 & 0.6 & 0.4 & 0.4 & 0.4 \\
Ak21 & 0.2 & 0.2 & 0.2 & 0.2 \\
ETA22 & 0.3 & 0.4 & 0.3 & 0.4 \\
Ctrl 1 & 0.1 & 0.01 & 0.04 & 0.01 \\
\hline
\end{tabular}

Source: Researcher's fieldwork (2008)

From Fig 2 A-D, quantities of SOx ranged between $(0.04-0.6 \mathrm{ppm}$ in polluted and 0.01 $0.3 \mathrm{ppm}$ in control areas), NOx $(0.1-0.5 \mathrm{ppm}$ in polluted and $0.01-0.04 \mathrm{ppm}$ in control), $\mathrm{CO}_{2}(0.1-$ $0.6 \mathrm{ppm}$ in polluted and $0.1-0.3 \mathrm{ppm}$ in control), and $\mathrm{CO}(0.01-0.7 \mathrm{ppm}$ in polluted and $0.001-$ $0.4 \mathrm{ppm}$ in control). Concentrations present in the 21 polluted mechanic workshops were higher than the standard set by World Health Organization and what was obtainable in the control except for Nst20 (Fig.3) that had less amount of all the gasses. In ground truth, huge obnoxious gas was seen everywhere in NST 20 environment but in the bar chart result; NST 20 (Fig. 4) had the lowest level of all the obnoxious gas. Asthana and Asthana (2005) opined that it takes 40-42 days to clear $0.01 \mathrm{ppm}$ of $\mathrm{Co}$ and $0.003 \mathrm{ppm}$ of $\mathrm{Co} 2$ from the atmosphere. The lower levels of all the obnoxious gasses displayed in NST20 may have been taken up by trees because NST 20 environment was also characterized by presence of trees. These trees may be instrumental to reduction of these obnoxious gases because they were measured less than 40-42 days.

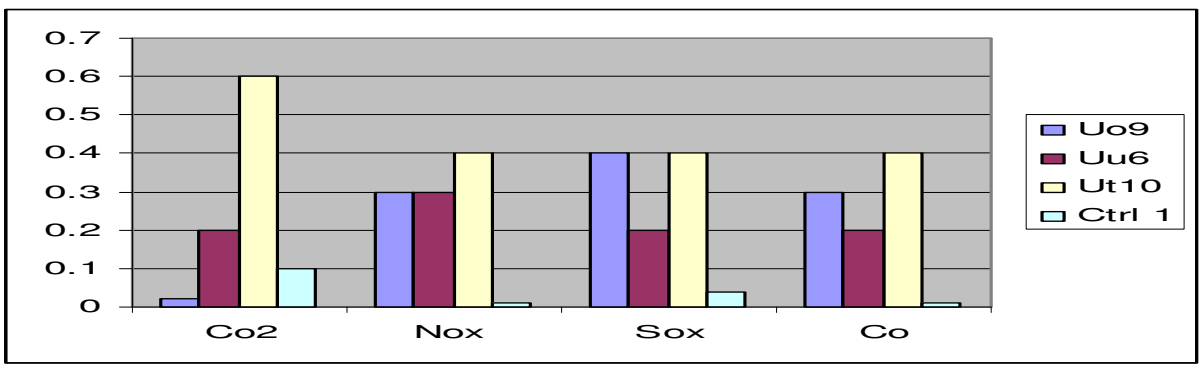

Figure 2 Bar chart comparing quantity of gases found in the polluted and unpolluted sites of the sample locations 


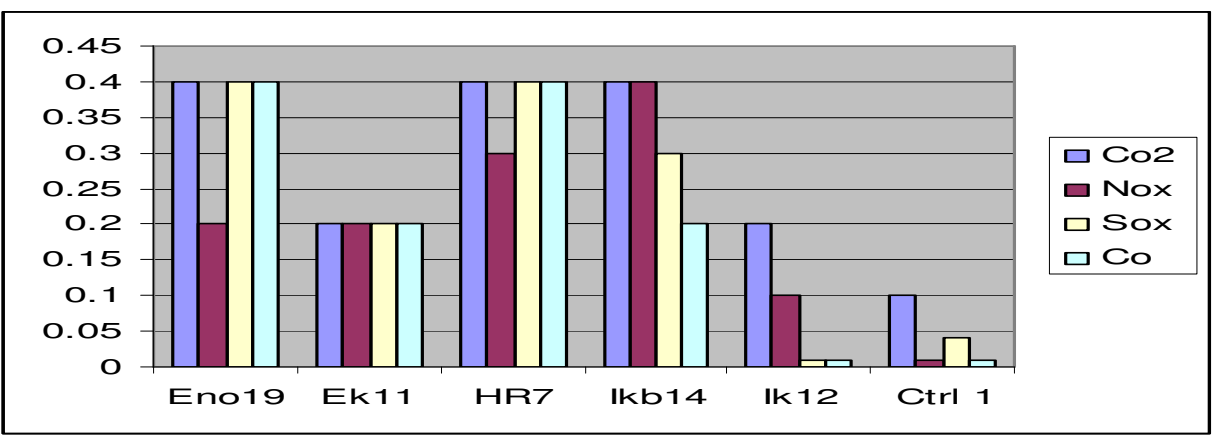

Figure 3 Bar chart comparing quantity of gases found in the polluted and unpolluted sites of sample locations

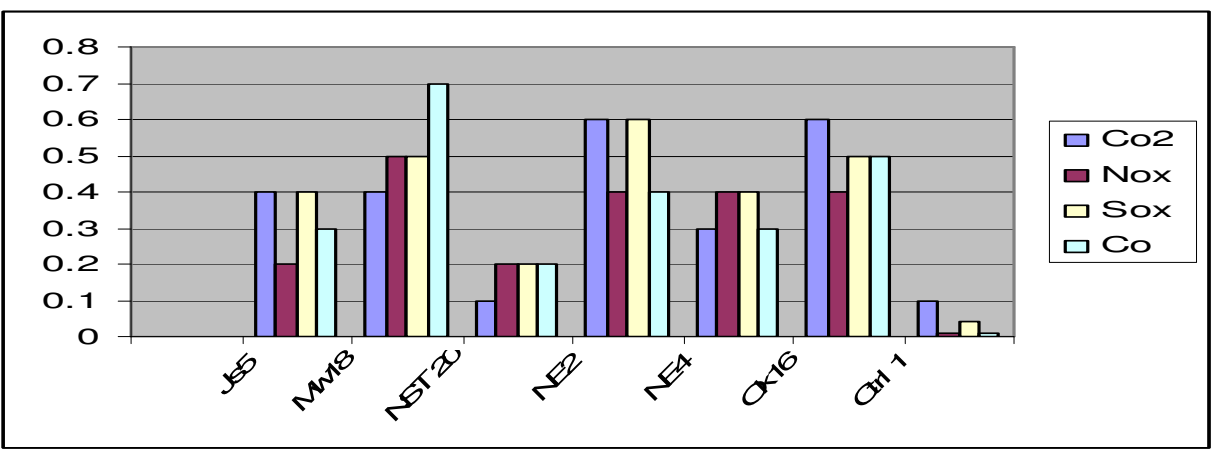

Figure 4 Bar chart comparing quantity of gases found in the polluted and unpolluted site of the sample locations

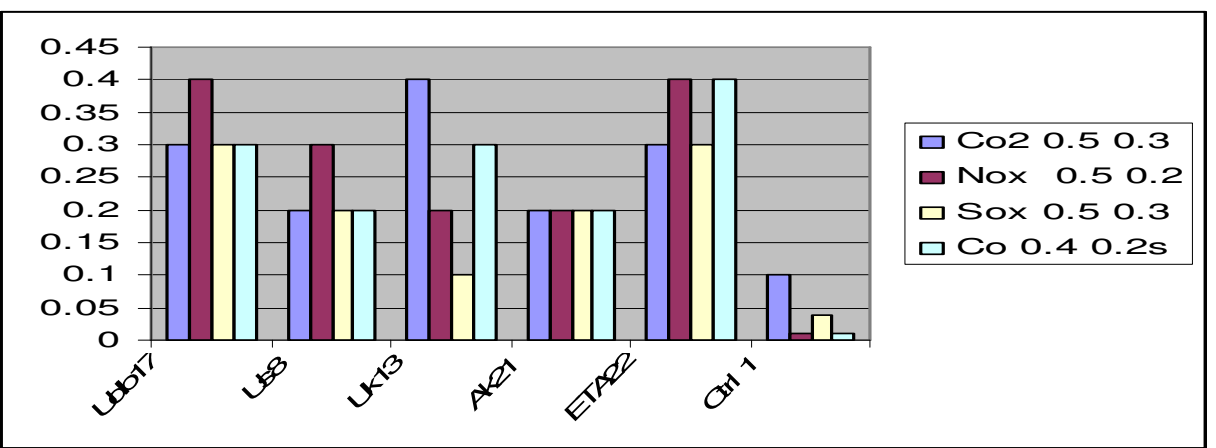

Figure 5 Bar chart comparing quantity of gases found in the polluted and unpolluted site of the sample locations

Assessment of Contributing Variables Affecting the Different Components of the U10-U13 of the Environment using Multiple Regression Analysis

Using the regression results in Table 2 (Quantity of $\mathrm{CO}_{2=} \mathrm{U} 10$ ) was caused by (D3 quantity of water), (D2 number of vehicles repaired per day), and (D1size of the workshop). Basseur (1990) observed that during riving of engines the car exhaust produce lots of air pollutants such as $\mathrm{CO}_{2}$, NOx. These gases may escape between pistons to the crankcase before they are discharged into the atmosphere. The principle conforms to real life situation observed during field work where operators kept riving old engines during repair hence, pumping huge amount of smoke. Bigger workshops had smokier environment than smaller ones (Fig. 4 and 5). When inhaled at concentration as low as $0.03 \mathrm{ppm}$, $\mathrm{CO}_{2}$ as noted by researchers can cause lots of discomfort and ailment to man. The scattered plot Figure 5 exhibited a strong positive relationship between the levels of pollution and the variables used. 
Table 2 Effects of independent variables D1-D7 on U10

Model summary

\begin{tabular}{|l|l|l|l|l|}
\hline Model & R & R square & Adjusted R square & Std. error of the estimate \\
\hline $\mathbf{1}$ & $.827(\mathrm{a})$ & .683 & .406 & .12252 \\
\hline
\end{tabular}

\begin{tabular}{l} 
ANOVA(b) \\
\begin{tabular}{|l|l|l|l|l|l|l|}
\hline Model & Sum of squares & Df & Mean square & F & Sig. \\
\hline \multirow{2}{*}{1} & Regression & .259 & 7 & .037 & 2.468 & $.115(\mathrm{a})$ \\
\hline & Residual & .120 & 8 & .015 & & \\
\hline & Total & .379 & 15 & & & \\
\hline a Predictors: (Constant), D7, D2, D4, D3, D6, D1, D5 & & & \\
\hline b Dependent variable: U10 &
\end{tabular} \\
\hline
\end{tabular}

\begin{tabular}{|c|c|c|c|c|c|c|}
\hline \multicolumn{7}{|c|}{ Coefficients(a) } \\
\hline & & \multicolumn{2}{|c|}{ Unstandardized coefficients } & \multirow{3}{*}{$\begin{array}{l}\text { Standardized coefficients } \\
\text { Beta }\end{array}$} & \multirow{3}{*}{\begin{tabular}{|l|}
$\mathbf{T}$ \\
1.034
\end{tabular}} & \multirow{3}{*}{\begin{tabular}{|l|} 
Sig. \\
.332 \\
\end{tabular}} \\
\hline & del & \multirow{2}{*}{$\begin{array}{l}\text { B } \\
.117\end{array}$} & \multirow{2}{*}{\begin{tabular}{|l|} 
Std. error \\
.113
\end{tabular}} & & & \\
\hline \multirow{8}{*}{1} & (Constant) & & & & & \\
\hline & D1 & $-6.227 \mathrm{E}-03$ & .003 & -.427 & -1.860 & .100 \\
\hline & D2 & $1.665 \mathrm{E}-02$ & .009 & .433 & 1.918 & .091 \\
\hline & D3 & $2.182 \mathrm{E}-03$ & .001 & .496 & 1.991 & .082 \\
\hline & D4 & $-1.662 \mathrm{E}-03$ & .006 & -.059 & -.289 & .780 \\
\hline & D5 & $2.667 \mathrm{E}-03$ & .006 & .141 & .477 & .646 \\
\hline & D6 & $4.895 \mathrm{E}-03$ & .012 & .101 & .412 & .691 \\
\hline & D7 & $-5.220 \mathrm{E}-04$ & .007 & -.016 & -.070 & .946 \\
\hline
\end{tabular}

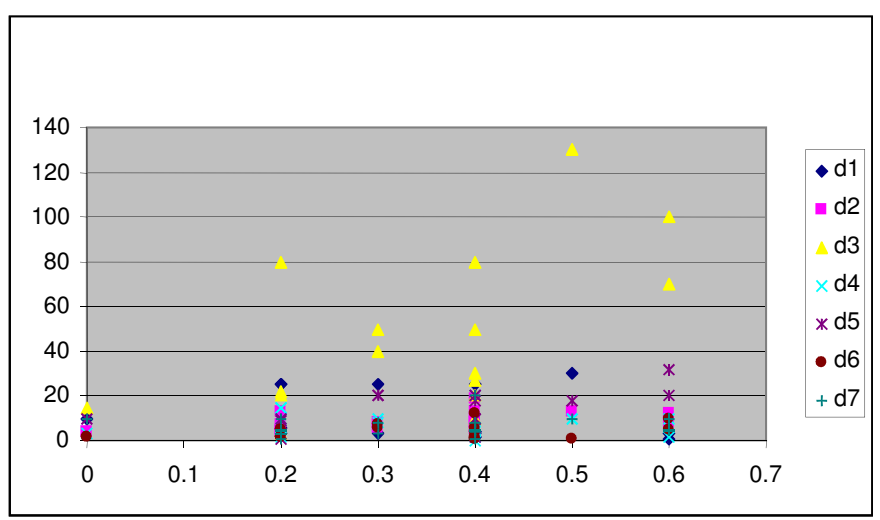

Figure 6 Scattered plot of U10 
From the regression result (Table 3) the quantity of Nitrogen oxide (U11) was affected by the joint contribution of amount of carbide (D4) and fuel (D5), quantity of dirty water (D3) and the number of vehicles repaired in a day (D2). The more these compounds are used indiscriminately the more nitrogen oxide was produced into the environment. This statistics agreed totally with what was observed during field work. Workshops operatives' burn carbides openly, spray fuel during riving of engines and throw dirty anti freeze water indiscriminately into the soil. The more the number of repairs the more the Nox generated. Larger workshops have higher level of Nox than smaller workshops.

This seems to agree with the work of (Uzoije, 2005) who observed that during vehicular repairs, man deposits about $20 \%$ of air pollutants into the atmosphere hence the reflection of number of vehicle repaired (D2) as a major contributor of NOx, $\mathrm{CO}_{2}$ and $\mathrm{CO}$. This relationship is positively exhibited by the scattered plot of U11 in Figure 7.

Table 3 Effects of independent variables D1-D7 on U11

\begin{tabular}{|l|l|l|l|l|}
\hline Model Summary \\
\hline Model & R & R square & Adjusted R square & Std. error of the estimate \\
\hline $\mathbf{1}$ & $.797(\mathrm{a})$ & .636 & .317 & .08993 \\
\hline a Predictors: (Constant), D7, D2, D4, D3, D6, D1, D5
\end{tabular}

ANOVA(b)
\begin{tabular}{|l|l|l|l|l|l|l|}
\hline Model & Sum of squares & Df & Mean square & F & Sig. \\
\hline & Regression & .113 & 7 & .016 & 1.993 & $.177(\mathrm{a})$ \\
\hline \multirow{3}{*}{$\mathbf{1}$} & Residual & .065 & 8 & .008 & & \\
\hline & Total & .178 & 15 & & & \\
\hline
\end{tabular}

\begin{tabular}{|c|c|c|c|c|c|c|}
\hline \multicolumn{7}{|c|}{ Coefficients(a) } \\
\hline & & \multicolumn{2}{|c|}{ Unstandardized coefficients } & \multirow{3}{*}{$\begin{array}{l}\text { Standardized coefficients } \\
\text { Beta }\end{array}$} & \multirow{3}{*}{\begin{tabular}{|l|}
$\mathbf{T}$ \\
.970
\end{tabular}} & \multirow{3}{*}{\begin{tabular}{|l|} 
Sig. \\
.361 \\
\end{tabular}} \\
\hline \multicolumn{2}{|c|}{ Model } & \multirow{2}{*}{\begin{tabular}{|l} 
B \\
$8.051 \mathrm{E}-02$ \\
\end{tabular}} & \multirow{2}{*}{\begin{tabular}{|l|} 
Std. error \\
.083 \\
\end{tabular}} & & & \\
\hline \multirow{8}{*}{1} & (Constant) & & & & & \\
\hline & D1 & $-1.586 \mathrm{E}-03$ & .002 & -.159 & -.645 & .537 \\
\hline & D2 & $5.720 \mathrm{E}-03$ & .006 & .218 & .898 & .396 \\
\hline & D3 & $5.518 \mathrm{E}-04$ & .001 & .183 & .686 & .512 \\
\hline & D4 & $8.417 \mathrm{E}-03$ & .004 & .439 & 1.996 & .081 \\
\hline & D5 & $5.355 \mathrm{E}-03$ & .004 & .414 & 1.305 & .228 \\
\hline & D6 & $-1.981 \mathrm{E}-03$ & .009 & -.059 & -.227 & .826 \\
\hline & D7 & $6.227 \mathrm{E}-03$ & .005 & .271 & 1.145 & .285 \\
\hline
\end{tabular}




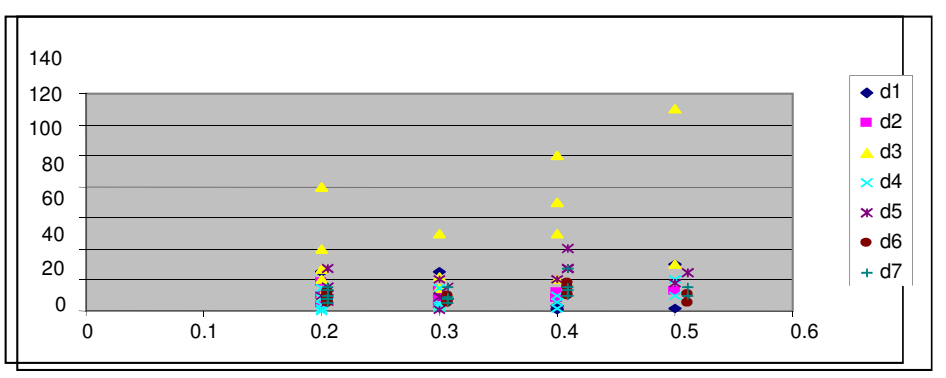

Figure 7 Scattered plot of U11

From Table 4 SOx - U12 was caused by D7 (paints), D5 (quantity of fuel), D3 (quantity of water) and D2 (number of vehicle repaired). In field survey, it was observed that mechanic operators spray paint cars in an open place void of spraying bouts hence the reflection of Paint (D7) as a major contributor to Sox formation. Paints contain thinner, lead, coatex, etc (Sax, 2001). Extracts of chemicals from quantity of fuel mixed with
NOx from riving of engines, paneling, vulcanizing, and other acidic volatile are known to be strong precursor of acid rain formation, which can corrode zinc and monument and cause accelerated slum formation (Weiss, 1980). This is supported by the fact that almost all the mechanic workshops observed were characterized by corroded zincs/ buildings. The scattered plot (Fig.8) also shows this positive relationship.

Table 4 Effects of independent variables D1-D7 on U12

Model Summary

\begin{tabular}{|l|l|l|l|l|}
\hline Model & R & R square & Adjusted R square & Std. error of the estimate \\
\hline $\mathbf{1}$ & $.834(\mathrm{a})$ & .696 & .429 & .10671 \\
\hline
\end{tabular}

ANOVA(b)
\begin{tabular}{|l|l|l|l|l|l|l|}
\hline Model & Sum of squares & df & Mean square & F & Sig. \\
\hline & Regression & .208 & 7 & .030 & 2.613 & $.101(\mathrm{a})$ \\
\hline \multirow{3}{*}{$\mathbf{1}$} & Residual & .091 & 8 & .011 & & \\
\hline & Total & .299 & 15 & & & \\
\hline
\end{tabular}

\begin{tabular}{|c|c|c|c|c|c|c|}
\hline \multicolumn{7}{|c|}{ Coefficients(a) } \\
\hline & & \multicolumn{2}{|c|}{ Unstandardized coefficients } & \multirow{3}{*}{\begin{tabular}{|l} 
Standardized coefficients \\
Beta
\end{tabular}} & \multirow{3}{*}{\begin{tabular}{|l}
$\mathbf{T}$ \\
1.165
\end{tabular}} & \multirow{3}{*}{\begin{tabular}{|l|} 
Sig. \\
.278 \\
\end{tabular}} \\
\hline \multicolumn{2}{|c|}{ Model } & \multirow{2}{*}{\begin{tabular}{|l|}
$\mathbf{B}$ \\
.115
\end{tabular}} & \multirow{2}{*}{\begin{tabular}{|l|} 
Std. error \\
.099
\end{tabular}} & & & \\
\hline \multirow{8}{*}{1} & (Constant) & & & & & \\
\hline & D1 & $-3.540 \mathrm{E}-03$ & .003 & -.273 & -1.214 & .259 \\
\hline & D2 & $1.128 \mathrm{E}-02$ & .008 & .330 & 1.492 & .174 \\
\hline & D3 & $1.537 \mathrm{E}-03$ & .001 & .393 & 1.610 & .146 \\
\hline & D4 & $2.885 \mathrm{E}-03$ & .005 & .116 & .577 & .580 \\
\hline & D5 & 7.082E-03 & .005 & .421 & 1.454 & .184 \\
\hline & D6 & $-1.801 \mathrm{E}-03$ & .010 & -.042 & -.174 & .866 \\
\hline & D7 & $-2.740 \mathrm{E}-03$ & .006 & -.092 & -.424 & .682 \\
\hline
\end{tabular}




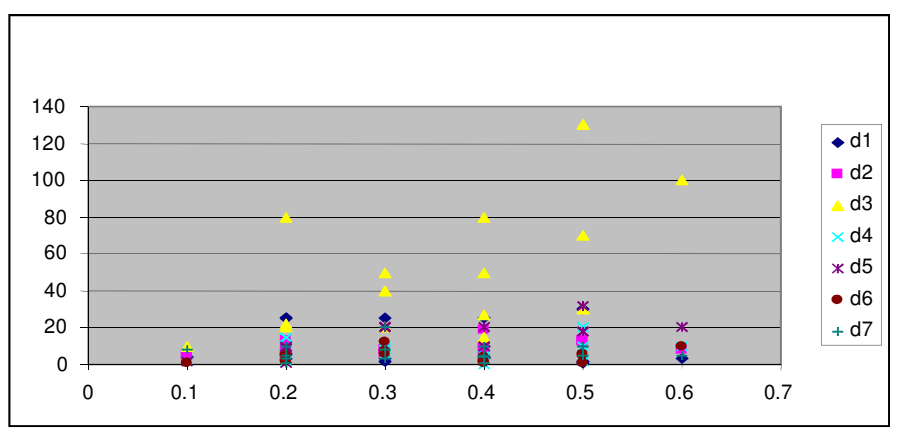

Figure 8 Scattered plot of U12

From Table 5 Carbon monoxide (U13) reflected quantity of fuel (D5) quantity of water (D3) and number of Vehicles (D1); as its major contributors. Vulcanizing activities, paneling, welding and other heat related activities are dummy variables of number of vehicles repaired in a day. These activities are known to load high level of raw $\mathrm{CO}_{2}$ into the atmosphere thus the high quantity of $\mathrm{CO}_{2}$ in the polluted environment than Table 5 Effects of independent variables D1-D7 on U13 unpolluted environment. The unpolluted environment was characterized by trees which absorb these $\mathrm{CO}_{2}$ for photosynthesis hence the drop in its quantity even when there was high level of burning and usage of fossil fuel for cooking (firewood). These workshops on the other hand had little or no trees to make use of the $\mathrm{CO}_{2}$ thus the high level.

\section{Model Summary}

\begin{tabular}{|l|l|l|l|l|}
\hline Model & R & R square & Adjusted R square & Std. error of the estimate \\
\hline $\mathbf{1}$ & .867 (a) & .751 & .534 & .09563 \\
\hline a Predictors: (Constant), D7, D2, D4, D3, D6, D1, D5 \\
\hline
\end{tabular}

\begin{tabular}{l} 
ANOVA(b) \\
\begin{tabular}{|l|l|l|l|l|l|l|}
\hline Model & Sum of squares & Df & Mean square & F & Sig. \\
\hline & Regression & .221 & 7 & .032 & 3.455 & $.052(\mathrm{a})$ \\
\hline \multirow{2}{*}{$\mathbf{1}$} & Residual & .073 & 8 & .009 & & \\
\hline & Total & .294 & 15 & & & \\
\hline a Predictors: (Constant), D7, D2, D4, D3, D6, D1, D5 & & & & \\
\hline b Dependent Variable: U13 &
\end{tabular} \\
\hline
\end{tabular}

\begin{tabular}{|c|c|c|c|c|c|c|}
\hline \multicolumn{7}{|c|}{ Coefficients(a) } \\
\hline & & \multicolumn{2}{|c|}{ Unstandardized coefficients } & \multirow{3}{*}{\begin{tabular}{|l} 
Standardized coefficients \\
Beta
\end{tabular}} & \multirow{3}{*}{$\begin{array}{l}\mathbf{T} \\
2.113\end{array}$} & \multirow{3}{*}{\begin{tabular}{|l|} 
Sig. \\
.068 \\
\end{tabular}} \\
\hline & del & \multirow{2}{*}{$\begin{array}{l}\text { B } \\
.187\end{array}$} & \multirow{2}{*}{\begin{tabular}{|l|} 
Std. error \\
.088 \\
\end{tabular}} & & & \\
\hline \multirow{8}{*}{1} & (Constant) & & & & & \\
\hline & D1 & $-7.287 \mathrm{E}-03$ & .003 & -.567 & -2.788 & .024 \\
\hline & D2 & $1.406 \mathrm{E}-02$ & .007 & .415 & 2.074 & .072 \\
\hline & D3 & $6.988 \mathrm{E}-04$ & .001 & .180 & .817 & .438 \\
\hline & D4 & $6.575 \mathrm{E}-03$ & .004 & .266 & 1.466 & .181 \\
\hline & D5 & $7.815 \mathrm{E}-03$ & .004 & .469 & 1.790 & .111 \\
\hline & D6 & $-1.285 \mathrm{E}-02$ & .009 & -.299 & -1.386 & .203 \\
\hline & D7 & $-5.600 \mathrm{E}-03$ & .006 & -.189 & -.968 & .361 \\
\hline
\end{tabular}


a Dependent variable: U13

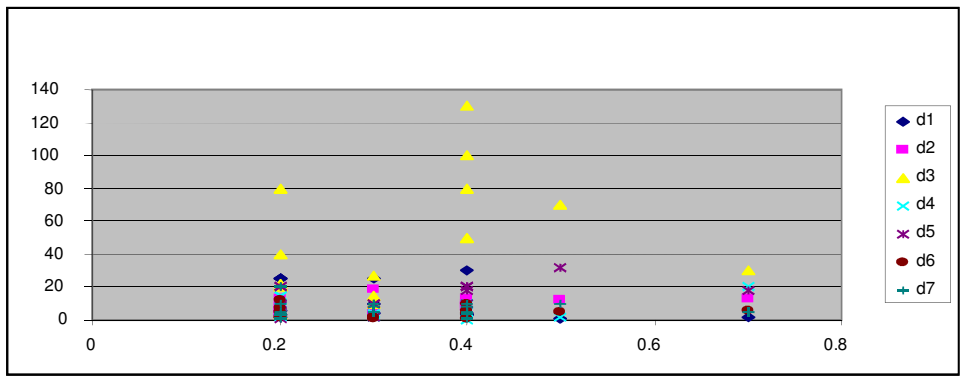

Figure 9 Scattered plot of U13

Testing of hypothesis

Table 6 Summary of $R$ and $R^{2}$ Values of all gases $\left(\mathrm{Co}_{2}\left(\mathrm{U}_{10}\right), \mathrm{No}_{\mathrm{x}}\left(\mathrm{U}_{11}\right), \mathrm{So}_{\mathrm{x}}\left(\mathrm{U}_{12}\right)\right.$ and $\mathrm{Co}\left(\mathrm{U}_{13}\right)$

\begin{tabular}{|l|l|l|}
\hline Gas Code & R Value & $\mathrm{R}^{2}$ Value \\
\hline $\mathrm{U} 10$ & .827 & .683 \\
$\mathrm{U} 11$ & .797 & .636 \\
$\mathrm{U} 12$ & .834 & .696 \\
$\mathrm{U} 13$ & .867 & .751 \\
\hline
\end{tabular}

From $95 \%$ confidence interval of $(.9565$, and $.6629)$, the R-values of all the regression results (Table 5), exhibited a very strong positive relationship. The $\mathbf{R}^{\mathbf{2}}$ is a tool of testing if a relationship is not a chance occurrence. Using the 95\% confidence interval of .9565 and .6629 as a yardstick for comparison, all the $\mathrm{R}^{2}$ value exhibited a confirmed strong relationship between mechanic activities and Uyo air pollution. A confirmation test offered by Bowerman and Richard, (1990) states that no relationship exists between dependent and independent variables if:

$$
\begin{aligned}
& \mathrm{H}_{\mathrm{o}}: \mathrm{Bd}+1=\mathrm{Bd}+2 \ldots \ldots . \mathrm{BK}=0 \text { but if } \\
& \mathrm{H}_{1}: \mathrm{Bd}+1=\mathrm{Bd}=2 \ldots \ldots . \mathrm{BK}=0
\end{aligned}
$$

then a relationship exist between the dependent and independent.

The remaining $25 \%$ unexplained variation may be due to pollution input from other artisan activities not mentioned in this work or may have been blown by wind into the vicinity. In this study, since none of the $R$ and $R^{2}$ values were zero, then there is a significant relationship between auto mechanic activities and the Uyo air polluted environment hence the acceptance of $\mathrm{H}_{1}$ and rejection of $\mathrm{H}_{0}$.

To prove further the acceptance and rejection of a hypothesis (Bowerman and Richard, 2003) postulated that should $\mathrm{F}$ values be greater than $\mathrm{S}$ values, $\mathrm{H}_{1}$ should be accepted while $\mathrm{H}_{0}$ is rejected and vice versa (Table 7).

Table 7 Summary of relationship between $\mathrm{F}$ and $\mathrm{S}$ values

\begin{tabular}{|l|l|l|l|l|}
\hline $\begin{array}{l}\text { Gas } \\
\text { Code }\end{array}$ & $\begin{array}{l}\mathrm{F} \\
\text { Value }\end{array}$ & $\begin{array}{l}\mathrm{S} \\
\text { Value }\end{array}$ & $\begin{array}{l}\text { Ratio } \\
\text { of } \mathrm{F} \text { to } \\
\mathrm{S}\end{array}$ & $\begin{array}{l}\text { Test to be } \\
\text { Accepted }\end{array}$ \\
\hline U10 & 2.468 & .115 & $\mathrm{~F}>\mathrm{S}$ & $\mathrm{H}_{1}$ \\
U11 & 1.993 & .117 & $\mathrm{~F}>\mathrm{S}$ & $\mathrm{H}_{1}$ \\
U12 & 2.613 & .101 & $\mathrm{~F}>\mathrm{S}$ & $\mathrm{H}_{1}$ \\
U13 & 3.455 & .052 & $\mathrm{~F}>\mathrm{S}$ & $\mathrm{H}_{1}$ \\
\hline
\end{tabular}

Since there is high $\mathrm{R}$ and $\mathrm{R}^{2}$ values for all the variables coupled with high $F$ values greater than $\mathrm{S}$ values, $\mathrm{H}_{1}$ is accepted. Therefore, there is a significant relationship between Uyo air pollution and mechanic activities necessitating the rejection of $\mathrm{H}_{0}$ that there is no relationship between auto mechanic activities and Uyo air polluted environment.

This implies that all the variables $\mathrm{D}_{1}-\mathrm{D}_{7}$ emanating from mechanic activities are increasing the pollution strength of $\mathrm{Co}_{2}, \mathrm{Co}, \mathrm{No}_{\mathrm{x}}$ and $\mathrm{So}_{\mathrm{x}}$ $\left(\mathrm{U}_{10}-\mathrm{U}_{13}\right)$ of Uyo air environment. If these variables (waste water $D_{3}$, fuel $D_{5}$, kerosene $D_{6}$, and paints $\mathrm{D}_{7}$ ) are handled sustainably, it will reduce drastically these air pollutants $\left(\mathrm{U}_{10}-\mathrm{U}_{13}\right)$ in the environment. 


\section{Conclusion}

There is an attempt in this study to assess the effects of auto mechanic activities on Uyo air environment. The objectives of this study were: to examine the different types of activities carried out in the environment and examine the air pollutants emanating from these activities, assess the individual and combine causes of air pollutants and to observe the relationship existing between auto mechanic activities and the air environment. These objectives were to enable us to make recommendations on ways of reducing the observed effects. To achieve these, a survey as well as in situ air analysis was carried out using hand held air meters, to measure the air pollutants found in the mechanic workshops and compared with control samples. Air contents were measured in each sample location after every one to six hours.

Activities carried out in these workshops included burning, welding, engine riving, paneling, air conditioning, open spray painting, volcansing, melting, etc. Results of air analysis show higher levels of obnoxious gases in polluted areas than in control areas. Multiple regression analysis shows a strong relationship between auto mechanic activities and the Uyo air environment at $95 \%$ level of significance.

\section{Recommendations}

Our environment is where we live (Wikipedia 2010) and for intergenerational equity must be protected especially with the current climate change. Every activity carried out in it should be performed in a way that it does not deviate so much from its natural carrying capacity. Activities carried out on the environment should be done with high level of sustainability. This study has shown that auto mechanic activities are scattered all over the city with no proper land use plan separating them from other uses especially residential and vegetables gardens. The study recommends that all the obnoxious gases should be reduced at source through proper land use zoning to ensure a sustainable air environment in the face of growing climate. To achieve such environment there is need to the following.

1. There should be proper land use zoning where the activities of this vital sector are confined to specific locations for easy management of wastes generated by it.
2. Planting of local phyto-remediation plants should be encouraged in all the workshops to help in the reduction of the obnoxious gases through the process of photosynthesis thereby making the air environment of these premises fresh all year round.

3. Car painting should be done in enclosed areas with less spraying so as to reduce obnoxious gas production into the atmosphere.

4. Mechanic workshops should be cited in environmental non-sensitive areas and residential land uses should be discouraged from migrating to such areas.

5. Planning authorities should set up a regulatory body to ensure that all auto mechanic workshops established within the metropolis apply for and receive consent in line with the planning provisions. This will help enforce compliance to the provision of the draft 2008 master plan.

\section{References}

Akwa Ibom State Government (AKS) (1986) Soil and Environmental Survey of Akwa Ibom state Report, 485 pages.

Asthana, D. K. and M. Asthana. (2005). Environmental Problems and Solution. $2^{\text {nd }}$ ed., New Delhi: Chand and Co, 55-80.

Atser, J., N. Etim, B. Ofem and F. Ekong (2010) "An overview of the changing pattern of rainfall and its implications for environmental and Agricultural Development in AKS, Nigeria: A case study" Journal of Agriculture and Social Science Vol.6 (3) pp65-72

www.fspublishers.org

Bassuer, G. (1987). The Endangered Ozone layer and New Theories of Ozone Depletion. The Environment 29 (1):20-27

Bowerman, B. L. and Richard, T. O. (1990). Linear Statistical Models: An Applied Approach $3^{\text {rd }}$ ed., Boston, MA: PWS - KENT Publishing Company, 457 - 974.

Bowerman, B. L and Richard, T. O. (2003). Business Statistics in Practice $3^{\text {rd }}$ ed., Ohio, Oxford.pp321- 320, 542- 543.

Dan-Klepal (2004) Mobile Mechanic; Guide to Environmental Best Practices pp2-5. American Environmental Protection Agency.

Earth Summit (2002) 'Pollution caused by Transportation' In: A new deal, Felix Dods (ed) Earthscans publication, London pp86-90 
Hall, S. K, (1972) Sulphur Compounds in the Atmosphere. Chemistry, 45:16.

Ipeaiyeda, A. R. and M. Dawodu (2008) 'Heavy Metals contamination of topsoil and dispersion in the vicinities of reclaimed auto-repair workshops in Iwo Nigeria' Bulletin of Chemical society Ethiopia 22(3) 339-348

Iwegbue, C. M. (2007) 'Metal fractionation in soil profiles at automobile mechanic waste dumps around Port Harcourt' Waste Management resource 25(6), 585-593

Robinson, E. and Robinson, B. B.(1970) Gaseous Nitrogenous Compounds. Pollutants from Urban and natural sources. Journal of Air Pollution Contr. Association 20, 303- 311.

Sax, N.I. (2001). Industrial Pollution, $4^{\text {th }}$ ed., Van Nost and Reinhold Ltd

Uzoije ,U. (2005). The impact of Urban runoff on Ogbor River, Department of Environmental Technology, Federal University of Technology, Owerri, Nigeria.
Weiss, M.A (1980). The Origins and Legacy of Urban Renewal in Urban and Regional Planning, New York Paragon Press Inc.

Wong, M. H. and Lau, W. (1985). Root Growth of Dicotlidone and Eleusine indicia collected from Motorways at different Concentrations of Lead. Environmental Report

World Health Organization (1990). Hazards of Human Environment, $3^{\text {rd }}$ Edition Geneva Convention

Wikipedia (2009) Auto mechanic, Free Encyclopedia, accessed online en.wikipedia.org/wiki/auto_mechanic on $20^{\text {th }}$ Sept 2010

Encyclopedia, accessed online en.wiwkipedia.org/wiki/land use planning on $10^{\text {th }}$ Oct.2011 